\title{
SIXTY YEARS OF RAE: A JOURNEY OF CRITICISM, RESISTANCE AND REINVENTION
}

\author{
Sessenta anos de RAE: Um itinerário de críticas, resistências e reinvenções \\ Sesenta años de RAE: Una trayectoria de críticas, resistencias y reinvenciones
}

Carlos Osmar Bertero' ${ }^{1}$ carlos.bertero@fgv.br | ORCID: 0000-0001-9813-088X

${ }^{1}$ Fundação Getulio Vargas, Escola de Administração de Empresas de São Paulo, São Paulo, SP, Brazil

\begin{abstract}
This article reflectively deals with the course taken by the journal over the 60 years it has been in existence, based on the author's experience as someone who was been associated with RAE-Revista de Administração de Empresas for all these years. We deal with its beginning as a pioneering periodical of business administration that divulged concepts, theories and practices that are predominantly American in origin, until we reach today when it emerges as a journal that has left behind its generalist origin and has begun to emphasize areas such as Organization and Organizational Studies, Strategy and Human Resources or People Management. Initially as a journal that was identified with a business school, FGV EAESP, it became a Brazilian journal with its own authors, consultants and associate editors from other institutions, and today it is working to establish itself as an international journal that is published in Portuguese and English, and that deals with contemporary topics mostly from a critical perspective. The growing methodological sophistication of the journal and the topics it publishes are a far cry from the early years, when it was a journal we could consider to be provincial. There is no doubt that we have made progress. Congratulations and a happy 60 years to RAE.
\end{abstract}

KEYWORDS | Internationalization, management, critical, RAE journal, management theory and practice.

\section{RESUMO}

O artigo trata, de maneira reflexiva, do itinerário da revista ao longo dos seus 60 anos de existência, a partir da experiência do autor, que foi ligado à RAE-Revista de Administração de Empresas ao longo dessas décadas. Abordamos seu início como periódico pioneiro de Administração de Empresas ou Negócios, divulgando conceitos, teorias e práticas de origem predominantemente americana, até os dias atuais, em que emerge como revista que deixou para trás a sua origem generalista e passou a enfatizar áreas como Organização e Estudos Organizacionais, Estratégia e Gestão de Recursos Humanos ou Pessoas. No início, um periódico identificado com uma escola de Administração, a FGV EAESP, passou a uma revista nacional, abrigando autores, consultores e editores associados de outras instituições para, atualmente, laborar para fixar-se como periódico internacional, sendo publicado em português e inglês e atendo-se a tópicos contemporâneos majoritariamente de uma vertente crítica. A crescente sofisticação metodológica da revista e os temas publicados colocam-nos muito distantes dos primeiros anos, em que era uma revista que poderíamos considerar provinciana. Não há dúvida de que avançamos. Parabéns e felizes 60 anos à RAE.

PALAVRAS -CHAVE I Internacionalização, management, crítica, Periódico RAE, Gestão-teoria e prática.

\section{RESUMEN}

El artículo trata, de manera reflexiva, la trayectoria de la revista a lo largo de sus 60 años de existencia, a partir de la experiencia del autor, que estuvo vinculado a la RAE-Revista de Administração de Empresas durante estas décadas. Abordamos su inicio como una revista pionera de Administración de Empresas o Negocios, difundiendo conceptos, teorías y prácticas de origen predominantemente estadounidense, hasta la actualidad, en la que surge como una revista que dejó atrás su origen generalista y comenzó a enfatizar áreas como Organización y Estudios Organizacionales, Estrategia y Gestión de Recursos Humanos o Personas. Lo que al principio era una revista identificada con una escuela de Administración, la FGV EAESP, se convirtió en una revista nacional, albergando a autores, consultores y editores asociados de otras instituciones y, actualmente, aúna esfuerzos para consolidarse como una revista internacional, publicada en portugués e inglés y que se atiene a temas contemporáneos, en su mayoría de aspecto crítico. La creciente sofisticación metodológica de la revista y los temas publicados nos alejan mucho de los primeros años, en los que era una revista que podríamos considerar provinciana. No cabe duda de que hemos avanzado. iFelices 60 años a la RAE!

PALABRAS CLAVE I Internacionalización, management, crítica, Revista RAE, Gestión teoría y práctica. 


\section{INTRODUCTION: A LITTLE OF THE CONTEXT}

RAE-Revista de Administração de Empresas was one of the first journals to deal with administration in Brazil. It was preceded by Rausp Management Journal of the University of São Paulo (Universidade de São Paulo [USP]) and by RSP-Revista do Serviço Público, which were founded in 1947 and 1937, respectively. RAE started in 1961 and is celebrating its sixtieth anniversary this year. As I twice had the opportunity and honor to occupy the position of director and editor of the journal, I was kindly invited by its current director, Maria José Tonelli, to write this article for this special issue.

The journal was the first to deal specifically with business administration. It was set up shortly after Getulio Vargas Foundation (Fundação Getulio Vargas [FGV]) took the initiative to create a business management school in the city of São Paulo in 1954. In launching a journal, the Sao Paulo School of Business Administration (Escola de Administração de Empresas de São Paulo [EAESP]) was looking to create a periodical that would consolidate its presence in the business and academic environment of São Paulo.

As the years and decades passed, the journal has become firmly established, and is now a respectable sixtyyear-old, having undergone various changes. Parodying biology, in which living organisms are transformed over time and in interaction with their environments, RAE has been transforming as the result of its interaction not only with the São Paulo business and academic environment. It has also become a periodical that has a Brazil-wide reach and repercussion, and is currently moving towards establishing its reputation internationally in a world in which academia and companies have also become multilateral.

Overcoming any natural feeling of triumphalism, the moment is very opportune for us to take this opportunity to look reflectively at the journal and see to what extent the course of the periodical allows us to observe what happened in administration, and specifically in business administration, over these six decades. This is no small task, because the period we are considering was one in which the most transformations in human history occurred. It has already been pointed out that those who lived in the period between the Second Industrial Revolution, which began in the United States and England around 1880, and today have witnessed transformations in number and nature that have no precedent in human history.

Over the past century our country has undergone transformations that were the biggest and most important ever recorded in our history. From Portuguese America, Brazil became a parliamentary constitutional monarchy, followed by a presidential republic. These political changes were not marked by any substantial economic changes. When the First Republic began, Brazil still had an economy that was little different from what it had been in the colonial period. But the 20 th century brought about substantial changes, not only in the economy, but especially in society and in politics. Not being a compulsive advocate of Enlightenment thinking, I believe that changes are not necessarily always better.

It is a well-known fact that we emerged economically over the past century to become one of the largest economies in the world. Today, we are part of the G20 and our GDP is among the largest, although sadly declining. RAE emerged during this moment of great strength and transformations in the Brazilian economy, whose growth was driven by industrial development, and FGV's School of Business Administration, which was home to the journal, was created to educate the new administration professionals who would be dedicating themselves to private or corporate administration, and specifically industrial corporations.

This article will follow a line of free reflection. Other texts have already dealt with RAE using different methodologies. I mention here the work by Favaretto and Francisco (2017), who used data mining methodology 
to reveal facts and relationships that neither the authors nor Ms. Tonelli (2018) expected, in which undertook a content analysis of material published by the journal and selected by the author. I used both works, and they helped me a lot to mature what I have written below. I could also not fail to mention the two texts I wrote on the occasion of the 45th and 50th anniversaries of RAE (Bertero, 2006, 2011).

$R A E$ reflected on and took part in important changes in fields of knowledge and action, as is the case with Administration, which is still being shaped and is known to have a small and volatile theoretical heritage. This can be found throughout the pages of the journal. It started out with a very modest purpose from an academic point of view, which was to spread knowledge in the Brazil about a still emerging area, business administration. It was not concerned with being original - nor did it expect to be - or with presenting discussions about rigor and relevance. It was assumed that it would be relevant to publish things in Portuguese that, even if they did not add anything new to the field of Administration, had never been published in Brazil before. For many years this was reflected in the large number of articles that were almost always translated from English, and taken from American publications.

There was no concern with striking a balance between practical content that could be useful to administration professionals, and theoretical texts that were of more interest to us few academics who found ourselves in the country at that time. We must not forget that full time employment for teachers in federal public universities only advanced in the 1970 s/80s, when it began to apply to a significant percentage of the professors. Full time jobs in private institutions were practically non-existent, with rare exceptions. For a long time, the administration professors among us were still professionals who dedicated a few hours a week to teaching, or later, teachers who earned their living exclusively from the teaching profession, but who, in order to survive, had to work frequently up to 40 hours a week in the classroom. None of this could characterize academic life as we understand it today.

\section{SOME POINTS ALONG THE WAY}

Like most foreign journals dedicated to company or business administration, RAE started life with a generalist purpose. Even today. several of these journals are generalist in nature, such as the Harvard Business Review, the California Management Review and the MIT Sloan Management Review, but the trend is towards specialized periodicals. As a generalist journal, in the early years RAE published exclusively material on business administration, and the articles could be classified as fitting the various functional areas of administration. With due liberty, we can say that these areas were those defined by Fayol in his 1925 classic (Fayol, 1990).

Over the years RAE has never abandoned its generalist editorial policy, but has tended to favor some administrative areas or functions more than others. The clear tendency is to find a greater number of articles that focus on Human Resources, Organizations and Strategy, and fewer articles dedicated to Finance, Management Accounting, Operations, Production, Marketing and Informatics. In the journal's first twenty or thirty years, it could be said that professors in these areas focused more on the professional consultancy market, but this is no longer true after the 1990s, when graduate programs, especially stricto sensu programs, included professors whose priority was teaching and research in the areas mentioned.

FGV's School of Business Administration in São Paulo ended up offering an undergraduate program in Public Administration in 1968. We have, then, an experiment that was successful in keeping business administration and public administration under one roof. This led RAE to start publishing public administration material in the 
1970 s/80s. But here an observation is appropriate. The publications and the very nature of the public administration courses at the school focused more on the formulation of public policy than on public management itself. These materials declined and practically disappeared from $R A E$ as periodicals that were specifically aimed at the public area began to appear, such as the Brazilian Journal of Public Administration (RAP-Revista de Administração Publica), linked to the FGV's Brazilian School of Public and Business Administration (Escola Brasileira de Administração Pública e de Empresas [EBAPE]), which started in 1967, and Organizações \& Sociedade, linked to the Administration program of the Federal University of Bahia (Universidade Federal da Bahia [UFBA]), which was launched in 1993.

Administration was not the only area to be published by the journal. Administration in Brazil has long been classified as an applied social science. There is no doubt that it is applied, but there are a lot of doubts and reservations among administration academics and, especially among social scientists, as to whether it is a social science. I do not think that economists, sociologists, social psychologists, anthropologists, political scientists or historians see Administration as a "sister" field; maybe a cousin, or even a second cousin for some. But as there is no denying the proximity, mixture and use of various social sciences in certain areas that are administrative matters for us, it has meant that many published articles can be seen as relating typically to the social sciences, and therefore could be published in periodicals that are specifically devoted to these respective social sciences.

But these very academic and even epistemological reasons for trying to establish limits and boundaries between the different sciences and areas of knowledge do not explain the political reason why RAE published social science articles for a certain period. I am referring here to the darkest period of the exception regime that was established in Brazil following publication of Institutional Act No. 5 (Al-5). The period was classified as one of blatant dictatorship (Gaspari, 2014), and among all the repression and disrespect for human rights that occurred it is worth remembering that there was a clear persecution of the social sciences, which made even the international academic community fear for their future in Brazil. It led to censorship and fear among authors and the editors of academic social science journals.

Because of FGV's "technocratic" stance, its schools and periodicals were relatively preserved during this dark time. This meant that RAE was able to publish material relating to the social sciences, specifically economics, which contained criticisms of the military government's economic policy.

This was a time in Brazil when the darkest period of the dictatorship coincided with the government's own proclamation of an "economic miracle," when the Brazilian economy registered unprecedented rates of growth of its GDP of more than $10 \%$ a year. But in this scenario, opposition to the regime had no outlets for expressing itself, since the all of the media, both spoken and written, was censored. It is appropriate to remind young people that in the 1960s/70s we did not yet have the Internet or the ubiquitous cell phones. Academic journals were also harassed by the regime's censors.

The journal published an economic article dealing with income distribution, which was the most trenchant criticism and perceived, at the time, as the only one that was made against the then economic policy, which was a relative increase in poverty due to the undeniable concentration of income.

The subject of income concentration is now a common subject in economic literature and that of other social sciences, and it even concerns liberal or neoliberal economists, but in the darkest period of the dictatorship the subject was considered to be clearly subversive, with all the connotations and threats that this adjective implied at the time.

After that moment had passed, and with the end of the dictatorship RAE continued concerning itself with social sciences. It started receiving articles that could also be published in periodicals dedicated to the various social sciences. 
Business Administration has been presented as arriving in Brazil from a decisive American influence. Much has been written and reflected upon among Brazilian authors with regard to the word "management" and what it means. We have even had bitter criticisms which preach abandoning once and for all American management and its repercussions, only to find those who defend it and see it as really welcome, and meaning rationality, efficiency, effectiveness and the promise of better quality management in the service of society.

Without getting into this debate, it would be wrong to take management as the only influence on the formation of an academic and professional field of Administration in Brazil. There have been other influences, and in particular those that came from Europe. In decreasing order of importance, we would mention the United Kingdom and France. The importance of France is reviewed in an article by Jean-François Chanlat that is being published simultaneously in $R A E$, and that deals with the French influence in our country. There is no denying that it was the greatest of the influences coming from Europe until the 1950s. The overwhelming influence of the United States was only felt from the 1950 s/60s, and was linked to the might of that country as a world superpower. This movement also resulted in the triumph of the English language, which became practically a lingua franca for academia and professional use. French in Brazil quickly disappeared, and today it is no longer adopted as the main foreign language, even though French thinkers have an undeniable impact on the Brazilian Academy of Administration.

In the case of RAE, it is important to remember that the Organizations/Organizational Studies areas and the preparatory disciplines of Sociology, Economics, Psychology, Political Science and, more recently, Philosophy were taught at FGV's Sao Paulo School of Business Administration by Brazilian teachers who were educated entirely in Brazil in the respective areas. These areas in Brazil, and particularly in São Paulo, were introduced in higher education from French university missions that were based at the University of São Paulo from the 1930 / 40 s, that is, as soon as that university was founded. Therefore, the mark of a French education is present in Brazilian social sciences, and this is manifested in the predominantly critical articles published by RAE.

EAESP was analyzed as the result of a process started by an American mission from Michigan State University, which brought a concept of business management that identified entirely with American management, but that subsequently became hybridized as a result of French and English influences. (Alcadipani \& Bertero, 2014).

RAE's governance also deserves attention. It started as an FGV EAESP journal, publishing material written almost exclusively by professors from the school. The universe of authors gradually expanded to include teachers from other Brazilian institutions. It was only from the end of the 1990 s that the question clearly arose of expanding the journal's horizon and making it part of an internationalization project. This led to a debate and, finally, to publishing texts eventually in English. We now have a bilingual magazine, in which all the published material appears in both Portuguese and English.

Also with regard to governance, at the end of the last century the journal created an editorial board, which also comprised members of other institutions, both Brazilian and from other countries. For a long time, the journal had only one director, who was also the editor and responsible for managing it. He was supported by professors who acted as consultants, gave their opinions and suggested publication or rejection. They were the predecessors of the current referees, who play a more complex role and can often also become the anonymous co-authors of much of what is published. In this line, the journal adhered to international practice, which arrived in Brazil at the end of the last century, of submitting all the material to be published to at least one double blind review. Referees included professors from other Brazilian and foreign institutions. 


\section{IN CONCLUSION: RAE TODAY}

What is RAE today? It is an important Administration journal that is not necessarily linked just to business administration, but also includes social or third sector organizations, and sometimes articles from the social sciences that border on Administration, or that are used by Administration as analysis tools and sources of inspiration. In the classification of journals carried out by Coordination for the Improvement of Higher Education Personnel (Coordenação de Aperfeiçoamento de Pessoal de Nível Superior [CAPES]), RAE has an A2 ranking, which recognizes it as an international-level journal. Although I have no information on the selection process or the number of submissions versus publications, I conclude it must be high, reaching more than a dozen submissions for each article that is published. This indicates the journal's prestige and the search by members of the academic community to be published in its pages.

Editorially too it has been updated, and the editor-in-chief has now been joined by a group of associate editors who not only help her with the large number of submissions, but also became necessary due to the specialization of the area and the impossibility of a single person to dominate the broad spectrum that today constitutes the Administration/Management area.

Certainly, RAE can be seen as reflecting and simultaneously participating in the creation of an academic field of Administration and, in its origin, also influencing the practice of administration by addressing the community of administration professionals (Tonelli, 2018). It is a truism, but needs to be said; recognizing that the Administration area had undergone many transformations, as a consequence and given all the changes that had occurred, RAE ended up adopting options in terms of its own content.

An important change in the area was the increase in the distance between academia and the world of administration professionals. This led to an unnecessary dichotomy between rigor and relevance. But we must recognize that this is a difficult and serious problem, that an area that is intended to be practically and academically considered an applied social science should face such a situation. In the applied areas let us take Engineering, Medicine, Dentistry, for example; one cannot conceive of a brilliant academic who is not equally a competent practitioner of what they teach and research. No one can imagine a chest surgeon who had never performed surgery, or a gynecologist who had never touched a woman. At this crossroads and faced with the inevitable dichotomy, $R A E$ is today less involved with practice and applications than it was in the early decades of its existence. It must be recognized that this occurred because of the guidelines of the authors, and also because of the pressures that arose in the area, in which the assessment criteria of scientific periodicals ended up being an important factor in the construction of the gap between theory and practice.

When it first started being published, the journal sought to put together issues that were balanced, with articles and reviews that covered the various functional areas of Administration. There was tendency for this to disappear with articles that concentrated more on some areas (Organizations and Organizational Studies, Strategy and Human Resources) than others. There was also a concern with producing an edition with topical issues, which led to Forum being produced, but which is not published on a regular basis. It depends on a decision by the director in charge, by the associate editors, or as the result of initiatives by academics who volunteer to coordinate a specific topic. But when all is said and done, $R A E$ is nowadays a journal that focuses less on practice or management, and more on the publication of material that fits what is required for it to be classified and ranked as a scientific journal according to international standards. Clearly what is practical, applied or managerial has lost a relative amount of space in the periodical.

I believe that few would disagree that Brazil is an anachronistic country, and that RAE during the first twenty years of its existence could perhaps be seen as a journal that did not necessarily publish pioneering material; it 
mimicked what came from outside, mostly from the United States. Since the end of the last century, RAE has ceased to be a journal subject to anachronism to become a publication that divulges contemporary topics, problems and issues in Administration. This is also reflected in the care it takes with the methodologies it uses to produce the articles that are published and on the topic. In fact, I think it would be no exaggeration to say that the first issues are historical documents and testimonies, which can also be understood as the cracks through which we get glimpses of a museum of Administration.

The journal went international, and internationalization became part of Brazilian educational policy. Government programs and the assessment criteria generated by CAPES, National Council for Scientific and Technological Development (Conselho Nacional de Desenvolvimento Científico e Tecnológico [CNPq]) and other state and local organizations that foster research also pressed and are still pressing for internationalization. This includes journals as the front line in this process. RAE started publishing material from foreign authors, included professors from other countries as referees, appointed foreigners to its Editorial Board and organized Forums which foreign authors and organizers took part in. Internationalizing, however, is no easy task for a periodical from a country that is still seen as peripheral rather than central in current international stratification, while Portuguese is a barrier to this process. Portuguese is one of the most widely spoken languages in the world in number of speakers, most of whom, however, are functionally illiterate. Portuguese is clearly not a language of culture, which is understood as a language that is learned regardless of the interest that one may have in the history, literature or culture of those who speak the language. But RAE overcame this barrier by becoming a bilingual journal.

An important characteristic of $R A E$ today is that one of its distinctive features is publishing articles that are of a critical nature. The hybridization of the school of which it forms part ended up marking the journal. Before the direct influences from Europe in opposition to or complementing the American influence, depending on the case, existed, the journal already had collaborators who were clearly for critical content. Authors such as Henrique Rattner, Mauricio Tragtenberg, Fernando Claudio Prestes Motta and Luiz Carlos Bresser-Pereira published works in the first two decades of the journal's existence. This trend has become stronger over the years, and today we can say that a distinctive feature of the periodical is that it adopts a critical stance and publishes content that fits the presentation we found on the website of the Critical Management Studies Division of the Academy of Management (CMS).

From its origins until recently, the Academy of Management was undoubtedly American and a messenger for mainstream American management. But the Academy gradually changed and started internationalizing, and while today it still bears traces of its origin, it already includes people from all over the world. It was in this way, being receptive to authors from other countries and cultures, that it also began to include on its various committees and in events, people who distanced themselves from, and even opposed, the so-called mainstream. In this context, it ended up moving towards the creation of a division that would involve Academy participants who represented the various critical trends. Another development was the creation of a critical space in the various journals published by the Academy of Management. RAE, however, was a pioneer in critically debating the principles and practices of Business Administration.

The list of topics that belong to a critical approach to Administration and Management includes gender issues, with an emphasis on feminism-specific topics, which looks for equal conditions between genders, and deals also with issues of homosexuality and transsexuality. These topics involve the participation of women and the LGBTQ + question in the world of Administration. Although progress has been made, there is a strong prejudice against accepting these groups in positions of command, both in the executive line and in advisory services in organizations. 
The journal presents articles that criticize the business world, especially the way in which large corporations are currently managed, the primary focus being on shareholders, while at times considering other stakeholders, such as employees, consumers, suppliers and the community.

As the backbone of its strategies, favoring shareholders can result - and has resulted - in practices that do not necessarily contribute to social well-being and sustainability over the medium and long terms, whether of society, the ecological environment, or the companies themselves and the economic system.

This critical posture has adopted an attitude of reservation and contestation with regard to organizational theories and business strategies that rely mainly on functionalist sociologies and liberalizing economic doctrines. The critical approach has not spared the globalizing project, which has led to recent approaches, such as postcolonialism, being adopted.

It is also worth observing the critical approach of the Human Resources or People Management area, which has guided many of RAE's publications in recent years. There is great reservation with regard to the treatment of human beings as production resources, and it has called for opposition to the concept of managing resources, rather than people. This leads to relationships between superiors/subordinates and between peers in the workplace being reviewed, and there is clearly also the issue of ethnic and cultural minorities. When this area of people management is viewed critically, it is possible to observe the interface between various prejudices as being an obstacle to careers and promotion, salary discrimination, and discrimination in the selection and performance evaluation processes against ethnic, cultural and gender minorities.

All that remains for me to say in concluding is that we can only compliment the current board of RAE, its associate editors, those who have collaborated as referees, the management of the journal and the many authors who have written for it so that the journal could exist and continue to exist for the last 60 years. May it continue to express and shape the paths of management for a long time into the future.

\section{REFERENCES}

Alcadipani, R., \& Bertero C. O. (2014). Uma escola norteamericana no ultramar? Uma historiografia da EAESP. RAERevista de Administração de Empresas, 54(2), 154-169. doi: 10.1590/So034-759020140204

Bertero, C. O. (2006). A RAE nos seus quarenta e cinco anos. RAERevista de Administração de Empresas, 46(2), 114-117. doi: 10.1590/S0034-75902006000200008

Bertero, C. O. (2011). Meio século de RAE. RAE-Revista de Administração de Empresas, 51(3), 224-226. doi: 10.1590/ So034-75902011000300002
Favaretto, J. E. R., \& Francisco, E. R. (2017). Exploração do acervo da RAE-Revista de Administração de Empresas (de 1961 a 2016) à luz da bibliometria, Text Mining, Rede Social e Geoanálise. RAE-Revista de Administração de Empresas, 57(4), 365-390. doi: 10.1590/s0034-759020170407

Fayol, H. (1990). Administração industrial e geral: Previsão, organização, comando, coordenação e controle. São Paulo, SP: Editora Atlas.

Gaspari, E. (2014). A ditadura escancarada. Rio de Janeiro, RJ: Editora Intrínseca.

Tonelli, M. J. (2018). Revistas científicas em Administração: 0 papel histórico da RAE-Revista de Administração de Empresas na construção do campo acadêmico em Administração no Brasil. Cadernos EBAPE, 16(Edição Especial). doi: 10.1590/1679-395173941

\section{AUTHORS` CONTRIBUTION}

The author declares that participated in all stages of the development of the manuscript. From the conceptualization and theoretical-methodological approach, the theoretical review (literature survey), writing and final review of the manuscript. 